\title{
HEPATITIS C VIRUS INVESTIGATION IN PEMPHIGUS FOLIACEUS (fogo selvagem) PATIENTS
}

\author{
Heitor ROSA*, Regina MARTINS** and Bart VANDERBORGHT***
}

HEADINGS - Hepatitis C virus. Pemphigus.

Infection with hepatitis $\mathrm{C}$ virus (HCV) affects millions of individuals in the world, resulting in chronic liver disease like chronic hepatitis $(\mathrm{CH})$ and hepatocellular carcinoma (HCC). Brazil overall has a HCV prevalence of $1.23 \%$; in our region of central-west (States de Goiás and Mato Grosso) this prevalence is $1.04 \%{ }^{+}$. A wide spectrum of extrahepatic manifestations have been reported in $\mathrm{HCV}$ infection ${ }^{(7)}$. Among these, several dermatological disorders have been claimed in association with $\mathrm{CH}$. Cutaneous vasculitis (CV) attributable to deposition of cryoglobulins is the best doccumented of these associations ${ }^{(2,8)}$. Porphyria cutanea tarda (PCT) $)^{(5)}$ and lychen planus (LP) ${ }^{(2,9)}$ are also associated with HCV. Other skin disorders, including erythema nodosum $^{(3)}$, erythema multiforme ${ }^{(1)}$ are also considered. Brazilian Pemphygus foliaceus (fogo selvagem) (FS) is an blistering organ-specific autoimmune skin disease, mediated by auto-antibodies of the IgG class IgG4 subclass, supposed to be triggered by environmental factors ${ }^{(10)}$. FS is endemic in certain regions of Brazil, like Goiás, Paraná(4), São Paulo and
Mato Grosso, affecting agricultural workers and some indians tribes ${ }^{(6)}$.

We studied a group consisted of 126 FS patients, interviewed when they visited the outpatient ambulatory of dermatologic clinic, between August 1994 to July 1995. A questionnaire was applied to the group, in which age, sex, years of disease, medications they used, addiction and volume to alcohol, history of blood transfusion and smoking. FS blood samples were collected after interview and stored at $-40{ }^{\circ} \mathrm{C}$ until tested for anti-HCV.

Anti-HCV were detected by a third generation assay using a mixture of structural (core) and nonstructural antigens (NS3, NS4 and NS5) (Innotest HCV Ab-Innogenetics, Ghent, Belgium). The results are shown in Table 1.

FS individuals do not live in a closed institution but they are treated as outpatients, thus their exposition to viral infections is the same of that for general population of our region.

* Gastroenterology and Hepatology Service, Federal University of Goiás Medical School, Goiânia, GO, Brazil.

** Virology Laboratory, Tropical Pathology and Public Heath Institute, Federal University of Goiás, Goiânia, GO.

*** Innogenetics, Ghent, Belgium.

Forum on Prevalence of Virus C Infection in Brazil. XVI Brazilian Congress of Hepatology, October, 1997; Pousada do Rio Quente, GO, Brazil. Address for correspondence: Dr. Heitor Rosa - Serviço de Gastroenterologia e Hepatologia - Faculdade de Medicina da UFGO - 74605-020

- Goiânia, GO, Brazil. e-mail: hrosa@cultura.com.br 
Table 1 - Characteristics of studied Pemphygus foliaceus patients for HCV in Goiânia, GO, Brazil, 1995

\begin{tabular}{lc}
\hline $\mathrm{n}$ & 126 \\
Mean \pm SD age (years) & $41.5 \pm 14$ \\
Male/female & $57 / 69$ \\
Duration of the disease (years) & $12.6 \pm 9.8$ \\
Corticosteroids users & $100(79 \%)$ \\
Duration of corticosteroids use (years) & $11 \pm 9.3$ \\
Alcohol drinkers & $18(14 \%)$ \\
Smokers & $41(32 \%)$ \\
Blood transfused & $15(12 \%)$ \\
ALT (mean \pm SD) units & $22 \pm 12$ \\
Bilirrubine (mean \pm SD) $\mathrm{mg} / \mathrm{dL}$ & $1.0 \pm 0.8$ \\
Albumine (mean $\pm \mathrm{SD}) \mathrm{mg} / \mathrm{dL}$ & $4.38 \pm 0.63$ \\
Anti-HCV positive & None \\
\hline
\end{tabular}

We do not find any anti-HCV positive patient neither transaminase alterations in the group (mean 22U); thus the anti-HCV

prevalence among these patients is nonsignificant in comparison to our general population $(1.04 \%)$.
Besides FS, leprosy is another very important skin disease in this region of Central Brazil. In previous study we showed the overall prevalence of $1.8 \%$ to antibodies to hepatitis $\mathrm{C}$ in 126 Brazilians lepromatous (83 outpatients and 133 institutionalized ones). It is interesting to take into consideration the fact that both groups of skin diseases - FS and leprosy - are formed by immunocompromised patients and long-term users of corticosteroids.

In summary, unlikely other dermatological disorders like PCT, LP, CV and leprosy in which HCV was found in association, we are not able to demonstrate its presence in FS, suggesting that this skin disease is not a group of risk for $\mathrm{HCV}$ infection.

Rosa H, Martins R, Vanderborght B. Investigação de hepatite vírus $C$ em pacientes com fogo selvagem (Pemphigus foliaceus). Arq Gastroenterol 2000;37(1):42-3.

DESCRITORES - Pênfigo. Hepatite virus C.

\section{REFERENCES}

1. Antinori S, Esposito R, Aliprandi CA, Tandini G. Erythema multiforme and hepatitis C. [letter]. Lancet 1991;337:428.

2. Daoud MS, Gibson LE, Daoud S, El-Azhary RA. Chronic hepatitis $\mathrm{C}$ and skin diseases: a review. Mayo Clin Proc $1995 ; 70: 559-64$.

3. Domingo P, Ris J, Martinez E, Casas F. Erythema nodosum and hepatitis C. Lancet 1990;336:1377.

4. Empinotti JC, Diaz LA, Martins CR, Rivitti EA, Sampaio AS, Lombardi C, Sanches JA. Endemic Pemphigus foliaceus in western Paraná, Brazil (1976-1988). Cooperative Group for Fogo Selvagem Research. Br J Dermatol 1990;123:431-7.

5. Fargion S, Piperno A, Coppellini MD, Sampietro M, Francanzani AL, Romano R, Caldarelli R, Marcelli R, Vecchi L, Fiorelli G. Hepatitis $\mathrm{C}$ virus and porphyria cutanea tarde: evidence of a strong association. Hepatology 1992;16:1322-6.
6. Friedman H, Campbell I, Rocha-Alvarez R, Ferrari I, Coimbra CE, Moraes JR, Flowers NM, Stastny P, Fernandez-Viña M, OlagueAlcala. Endemic Pemphigus foliaceus (fogo selvagem) in native Americans from Brazil. J Am Acad Dermatol 1995;32:949-56.

7. Hadziyannis SJ. The spectrum of extrahepatic manifestations in hepatitis C virus infection. J Viral Hepat 1997;4:9-28.

8. Pakula AS, Garden JM, Roth SI. Cryoglobulinemia and cutaneous leukocytoclastic vasculitis associated with hepatitis C virus infection. J Am Acad Dermatol 1993;28:850-3.

9. Rebora A, Robert E, Rongioletti F. Clinical and laboratory presentation of lichen planus patients with chronic liver disease. J Dermatol Sci 1992;4:38-41.

10. Sampaio AS, Rivitti EA, Aoki V, Diaz LA. Brazilian Pemphigus foliaceus "endemic pemphigus foliaceus" or fogo selvagem (wild fire). Dermatol Clin 1994;2:765-76.

Recebido para publicação em 25/5/1999. Aprovado para publicação em 15/12/1999. 